\title{
Avaliação da ação de uma virose na produção e qualidade de tubérculos de batata-doce
}

\section{Action evaluation of a virus on yield and quality of sweet potato tubers}

\author{
Sônia Maria Nalesso Marangoni Montes ${ }^{1 *}$, Edison Martins Paulo', Rafael Marangoni Montes²
}

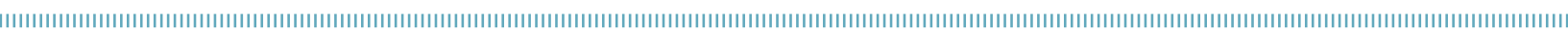

RESUMO: O oeste do estado de São Paulo responde por cerca de $40 \%$ da produção estadual de batata-doce, mesmo sem a adoção, pelos agricultores da região, de tecnologias fundamentais para o aumento da produtividade. Este trabalho avaliou o impacto de viroses sobre variáveis da produção de batata-doce. $\mathrm{O}$ experimento foi conduzido em área comercial no município de Presidente Prudente, São Paulo, Brasil, utilizando plantas de Ipomoea batatas L., grupo rosada, cv. Canadense. Como material de propagação foram utilizadas mudas livres de vírus produzidas em viveiros e mudas originadas de lavoura comercial infectada por vírus. Na colheita foram demarcadas três parcelas de 10 × $4 \mathrm{~m}$ em cada uma das metades do campo (com e sem vírus), quando se avaliou, aleatoriamente, número, massa, comprimento e diâmetro dos tubérculos de dez plantas localizadas na área central de cada parcela. As parcelas sem vírus produziram cerca de $50 \%$ a mais e o dobro em massa $(\mathrm{kg})$ de tubérculos colhidos em relação aos provenientes das parcelas com vírus. Os tubérculos obtidos das plantas não infectadas apresentaram maior massa $(\mathrm{p}<0,01)$, comprimento $(\mathrm{p}<0,01)$ e diâmetro médio $(\mathrm{p}<0,05)$ do que os colhidos das plantas infectadas. Foi constatada também uma frequência de $65 \%$ de tubérculos com classificação 2A (150 a 299 g) para o grupo rosada-CEAGESP, que representa $70 \%$ do volume comercializado no CEAGESP, o que confere maior lucratividade ao produtor.

PALAVRAS-CHAVE: Ipomoea batatas; qualidade; vírus; mercado.

\begin{abstract}
The Western region of São Paulo State, Brazil, is responsible for approximately $40 \%$ of the production of sweet potato (Ipomoea batatas L.) in the state, even under lowtechnology. The study aimed to evaluate the impact of viruses on sweet potato production variables. The experiment was conducted in Presidente Prudente, São Paulo, Brazil, in a commercial sweet potato crop of pink group, cv. Canadense, with and without virus. In three randomly chosen plots of $10 \times 4 \mathrm{~m}$ in each half of the field (with and without virus), ten central plants were randomly collected. The number, weight, length and diameter were evaluated. The plots without virus produced 50\% more tubers and $100 \%$ more weight during harvesting. Tubers obtained from virus-free seedlings showed a greater mass $(\mathrm{p}<0.01)$, height $(\mathrm{p}<0.01)$ and mean diameter $(\mathrm{p}<0.05)$ than those harvested from infected plants. From free-of-virus seedlings, 65\% of tubers were classified as $2 \mathrm{~A}$ (150 to $299 \mathrm{~g}$ ), the standard that represents $70 \%$ of the trading volume at a Food Market place, which provides greater profitability to the producer.
\end{abstract}

KEYWORDS: Ipomoea batatas; quality; virus; market.

\footnotetext{
${ }^{1}$ Apta Regional Alta Sorocabana (APTA) - Presidente Prudente (SP), Brasil.

Universidade Estadual Paulista (UNESP) - Jaboticabal (SP), Brasil.

*Autor correspondente: soniamontes@apta.sp.gov.br

Recebido em: 07/06/2013. Aceito em: 20/11/2014
} 
O oeste de São Paulo é uma das principais regiôes produtoras de batata-doce do estado. Apesar da importância econômica desse segmento do agronegócio, o cultivo dessa olerícola é realizado por pequenos produtores que náo utilizam tecnologias fundamentais para o aumento da produtividade. A ocorrência de viroses se destaca entre os fatores que mais causam prejuízos à produção de batata-doce, o que se deve à falta de material de propagaçáo sadio isento de agentes fitopatogênicos, e da disponibilização, aos agricultores, de cultivares resistentes às doenças. Na cultura da batata-doce, mais de 15 espécies de vírus (Valverde et al., 2007; Di Feo et al., 2000) já são descritos, entre os quais ocorrem no Brasil: o vírus do mosqueado plumoso (sweet potato feathery mottle virus - SPFMV); vírus do mosqueado suave (sweet potato mild mottle virus - SPMMV); o vírus latente (sweet potato latent virus - SPLV) e o que causa a mancha clorótica (sweet potato chlorotic flecks virus SPCFV) (Moyer; Salazar, 1989; Pio Ribeiro et al., 1993; Daniels, 1999; Кroth et al., 2001). Desses, o SPFMV é o mais disseminado, com ocorrência comum em todo o mundo, inclusive no Brasil, causando perdas significativas na produção (VALVERDE et al, 2007).

A produção comercial da batata-doce é baseada na propagação vegetativa, o que causa o acúmulo e a perpetuação dos vírus em praticamente todas as cultivares plantadas nas principais áreas do mundo, causando perdas significativas nos aspectos quantitativo e qualitativo dos tubérculos (CECílioFilho et al., 1998; Pozzer et al., 1994).

$\mathrm{Na}$ África, foram registradas perdas variando de $56 \mathrm{a}$ $90 \%$ em plantaçóes afetadas pela associação do SPFMV com SPCSV (NDUnguru et al., 2009).

No Brasil, estudo realizado na regiáo de Presidente Prudente, Sáo Paulo, mostrou que o emprego de material livre de vírus no plantio recupera a produtividade das cultivares, mesmo quando cultivadas próximas a plantios comerciais, expostos à pressão do inóculo de vírus (Montes et al., 2010).

O estudo objetivou avaliar o impacto da utilização de material de propagaçấo livre de vírus quanto aos padróes qualitativos e quantitativos da batata-doce. Para tanto, o experimento foi instalado em uma área de produção comercial de batata-doce situada no Distrito de Emilianópolis, município de Presidente Prudente, São Paulo, Brasil. No estudo foram utilizadas plantas de batata-doce (Ipomoea batatas L.) da cultivar canadense, grupo rosada, como fonte de material propagativo e de inóculo de vírus. $\mathrm{O}$ material propagativo infectado foi obtido de plantas provenientes de cultivos anteriores do produtor. A outra parte de plantas, isenta de vírus, foi produzida no setor de fitossanidade do Polo Regional de Desenvolvimento Tecnológico da Alta Sorocabana (PRDT-Alta Sorocabana)/Agência Paulista de Tecnologia dos Agronegócios (APTA). O plantio foi realizado em 02/10/2011 em leiras, com espaçamento de 0,90 x 0,30 m e adubação de $700 \mathrm{~kg} / \mathrm{alq}$ de 4-14-8. Na colheita, realizada aos 150 dias após o plantio, foram demarcadas aleatoriamente 3 parcelas de 10 metros de comprimento por 4 metros de largura em cada uma das metades do campo, com e sem vírus, em que se avaliaram, para cada parcela, número, massa, comprimento e diâmetro dos tubérculos das 10 plantas centrais, coletadas ao acaso. O diâmetro foi obtido por meio da medida da porção central dos tubérculos colhidos, utilizando um paquímetro.

$\mathrm{Na}$ análise dos dados de produção foi utilizada a estatística descritiva e aplicado o teste $t$ para comparação das médias das variáveis estudadas.

Foi constatado que as parcelas sem vírus produziram $50 \%$ a mais de tubérculos com o dobro de massa $(\mathrm{kg})$, quando comparados aos provenientes das parcelas com vírus. Os tubérculos obtidos das plantas sem vírus produziram maior massa ( $\mathrm{p}<0,01)$, comprimento $(\mathrm{p}<0,01)$ e diâmetro médio $(\mathrm{p}<0,05)$ quando comparados com as plantas infectadas (Tabela 1 ).

$\mathrm{Na}$ Companhia de Entrepostos e Armazéns Gerais de São Paulo (CEAGESP), a comercialização da batata-doce requer a classificação dos tubérculos do grupo rosada pela massa, nas seguintes classes: 1A (70 a 149 g); 2A (150 a 299 g); G (maior que $300 \mathrm{~g}$ ) (CEAGESP, 2012). No CEAGESP, $70 \%$ do volume comercializado de batata-doce pertence à classificação $2 \mathrm{~A}$ que, direcionado para mercados e quitandas, alcança o dobro do preço de mercado em relação às da classificação $1 \mathrm{~A}$ e G. As classificações 1A, normalmente adquirida por feirantes, e G, utilizada por cozinhas industriais, representam, respectivamente, 20 e $10 \%$ do volume total das vendas (CEAGESP, 2012).

Nas análises das plantas isentas de vírus, observou-se uma frequência de $65 \%$ de tubérculos com classificação $2 \mathrm{~A}, 24 \%$ de $1 \mathrm{~A}$ e $33 \%$ de G (Fig. 1). Nas plantas com vírus, observou-se uma frequência de $16 \%$ de tubérculos com classificação $2 \mathrm{~A}$, $61 \%$ de $1 \mathrm{~A}$ e $8 \%$ de $\mathrm{G}$ (Fig. 2).

A grande percentagem de tubérculos de batata-doce com peso entre 72 e $144 \mathrm{~g}$ obtida a partir do material com vírus evidenciou náo só a baixa produtividade, como também a grande percentagem de batata-doce com classificação

Tabela 1. Massa, comprimento e diâmetro dos tubérculos de batata-doce produzidos a partir de mudas com e sem vírus. Presidente Prudente, São Paulo, 2012.

\begin{tabular}{lcccccc} 
Tratamento & $\mathbf{n}$ & Massa total & Massa média & Comprimento & Diâmetro \\
\cline { 2 - 7 } & & & $\mathbf{k g}$ & \multicolumn{3}{c}{$\mathbf{c m}$} \\
Sem vírus & 124 & 26,04 & $0,210 \pm 0,014$ & $17,45 \pm 0,39$ & $4,29 \pm 0,18$ \\
\hline Com vírus & 86 & 11,56 & $0,134 \pm 0,012$ & $15,31 \pm 0,56$ & $3,94 \pm 0,14$ \\
\hline Teste t & & & $3,81^{*}$ & $3,24^{*}$ & $1,91^{* *}$ \\
\hline
\end{tabular}

*significativo a $1 \%$ de probabilidade; ** significativo a $5 \%$ de probabilidade 


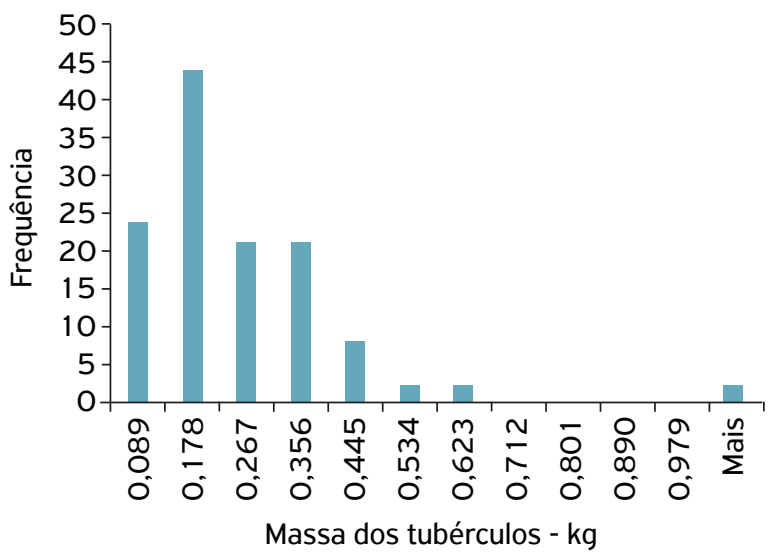

Figura 1. Frequência da massa dos tubérculos produzidos a partir de plantas sem vírus. Presidente Prudente, São Paulo, 2012.

de mercado abaixo do exigido, o que implica em um retorno financeiro $50 \%$ inferior ao esperado com participação de apenas $20 \%$ no mercado.

Os resultados evidenciam que a virose em batata-doce é um importante problema fitossanitário a ser controlado nos campos de produção pelo fato de limitar o desenvolvimento do

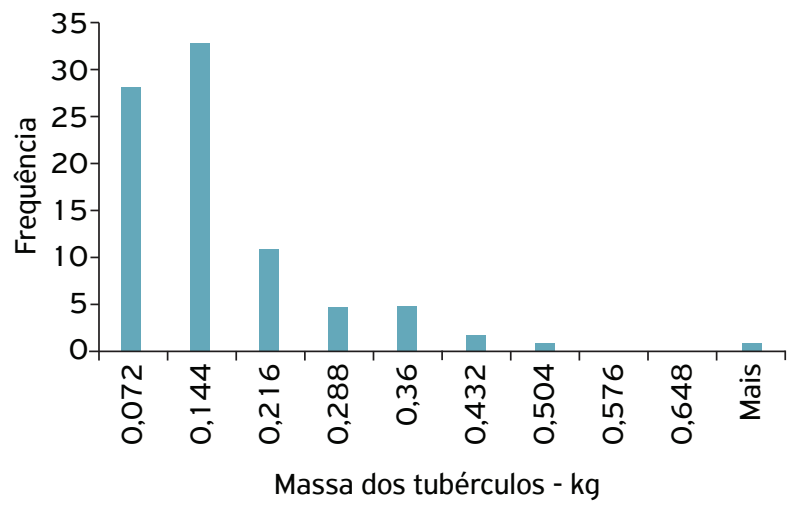

Figura 2. Frequência da massa dos tubérculos produzidos a partir de plantas com vírus. Presidente Prudente, São Paulo, 2012.

sistema radicular e/ou a tuberização das raízes e, consequentemente, a formação de tubérculos que serão classificados como pertencentes ao grupo de menor valor comercial restringindo a produtividade. Além de limitar a produtividade, o plantio de material infectado por vírus condiciona a formação de tubérculos de batata-doce com menor valor comercial.

| | | | | | | | | | | | | | | | | | | | | | | | | | | | | | | | | | | | | | | | | | | | | | | | | | | | | | | | | | | | | | | | | | | | | | | | | | | | | | | | | | | | | | | | | | | | | | | | | | | | | | | | | | | | | | | | | | | | | | | | | | | | | | | | | | | | | | | | | | | | | | | | | | | | | | | | | | | | | | | | | | | | | | | | | | | | | | | | | | | | | | | | | | | | | | | | | | | | | | | | | | | | | | REFERÊNCIAS

CEAGESP. COMPANHIA DE ENTREPOSTOS E ARMAZÉNS GERAIS DE SÃO PAULO. Orientador de Mercado. Adilson da Silva Munhoz (informação pessoal), 2012.

CECÍLIO FILHO, A.B.; REIS. M.S.; SOUZA R.J.; PASQUAL, M. Degenerescência em cultivares de batata-doce. Horticultura Brasileira, Brasília, v.16, n.1, p.82-84, 1998.

DANIELS, J. Utilização de técnicas sorológicas para detecção de vírus em batata-doce. Brasília: Embrapa/CPACT, 1999.

DI FEO, L; NOME, S.F.; BIDERBOST, E. Etiology of sweet potato chlorotic dwarf disease in Argentina. Plant Disease, v.84, n. 1, p.35-39, 2000.

KROTH, L.L.; FUENTES, S.; SALAZAR, L.F.; DANIELS, J. Detecção sorológica de vírus por NCM-ELISA em lavouras de batata-doce no estado do Rio Grande do Sul, Brasil. Revista Brasileira de Agrociência, v.7, n.2, p. 117-119, 2001.

MONTES, S.M.N.M.; RÓS-GOLLA, A.; PAULO, E.M. Produção de tubérculos de cultivares de batata doce na ausência e presença de vírus. Biológico, São Paulo, v.72, n.2, p. 103-170, 2010.
MOYER, J.; SALAZAR, L.F. Viruses and virus-like diseases of sweet potato. Plant Disease, v.73, p.451-455, 1989.

NDUNGURU, J.; KAPINGA, R.; SSERUWAGI, P.; SAYI, B.; MWANGA, R.; TUMWEGAMIRE, S.; RUGUTU, C. Assessing the sweet potato virus disease and its associated vectors in northwestern Tanzania and central Uganda. African Journal of Agricultural Research, v.4, n.4, p.334-343, 2009.

PIO RIBEIRO, G.; ASSIS-FILHO, F.M.; DA PAZ, C.D.; PIRES, C.R.C. Ocorrência de Sweet potato feathery mottle virus em germoplasma de batata-doce no Estado de Pernambuco. Fitopatologia Brasileira, v. 18, p.458-460, 1993.

POZZER, L.; SILVA, J.B.C.; DUSI, A.N.; KITAJIMA, E.W. Avaliação da taxa de reinfecção de plantas de batata-doce livre de vírus pelo Sweet potato feathery mottle virus em condições de campo. Fitopatologia Brasileira, v.19, n.2, p.23 1-234, 1994.

VALVERDE, R.A.; CLARK, C.A.; VALKONEN, J.P.T. Viruses and virus disease complexes of Sweetpotato. Plant Viruses, v.1, n.1, p. $116-126,2007$. 